\title{
Cultured and packed sea grapes (Caulerpa lentillifera): effect of different irradiances on photosynthesis
}

\author{
Lara Elisabeth Stuthmann $^{1}$ (D) $\cdot$ Karin Springer ${ }^{2} \cdot$ Andreas Kunzmann $^{1}$ \\ Received: 26 June 2020 / Revised and accepted: 4 November 2020 / Published online: 6 December 2020 \\ (C) The Author(s) 2020
}

\begin{abstract}
The green macroalga Caulerpa lentillifera (sea grapes, green caviar) is a promising source for future nutrition due to its beneficial composition for human consumption. It is cultured in tidal ponds, mainly in Vietnam and the Philippines, and stored for shipment and retail in plastic containers, like polystyrene (PS) and polyethylene terephthalate (PET), exhibiting different properties. This study investigates the influence of irradiances on the physiology of sea grapes under culture and packaging ambience in PET using pulse-amplitude modulated (PAM) fluorometry. $F_{v} / F_{m}$ values of $C$. lentillifera significantly decreased $<0.54 \pm 0.06$ standard deviation (SD) after 7 days of culture under $100 \mu \mathrm{mol}$ photons $\mathrm{m}^{-2} \mathrm{~s}^{-1}$, but with the potential of recovery. In packaging ambience in the state of desiccation, sea grapes exposed to room irradiances $\left(3 \mu \mathrm{mol}\right.$ photons $\left.\mathrm{m}^{-2} \mathrm{~s}^{-1}\right)$ for 12 days were still physiologically in a good condition $\left(F_{v} / F_{m}=0.70 \pm 0.06\right)$. However, 12 days under irradiances of $70 \mu \mathrm{mol}$ photons m $\mathrm{m}^{-2} \mathrm{~s}^{-1}$ leads to decreased $F_{v} / F_{m}(0.42 \pm 0.11)$ and a moisture content of $88.2 \pm 3.3 \%$ of initial. After re-immersion in sea water under room irradiances, $F_{v} / F_{m}$ values recovered to a certain degree. In darkness, desiccation was followed by a decrease of $F_{v} / F_{m}$ to $0.09 \pm$ 0.19 and moisture content of $49.3 \pm 20.2 \%$ of initial with no recovery after re-immersion under room irradiances. Results suggest shading of $C$. lentillifera in pond culture and PET containers as suitable packaging for sea grapes, but a dim light source should be provided during storage.
\end{abstract}

Keywords Aquaculture $\cdot$ Food $\cdot$ Green caviar $\cdot$ Packaging $\cdot$ Photosynthetic efficiency

\section{Introduction}

Seaweeds as a nutritious and abundant food product are one answer to an explosively growing and hungry world population (Pereira 2020). Many macroalgae naturally inhibit coastal zones, where they are exposed to fluctuations in physiochemical environmental conditions which influence their physiology such as intensities of photosynthetically active radiation (PAR) and desiccation (Davison and Pearson 1996). Other than in the natural habitat, in aquaculture settings, environmental parameters can be partially adapted to the needs of the organism as long as these conditions are known.

Sea grapes (Caulerpa lentillifera J. Agardh; Caulerpaceae, Bryopsidales) are green, siphonous macroalgae with a special

Lara Elisabeth Stuthmann

lara.stuthmann@leibniz-zmt.de

1 Leibniz Centre for Tropical Marine Research, Fahrenheitstraße 6, 28359 Bremen, Germany

2 University of Bremen, Bibliothekstraße 1, 28359 Bremen, Germany texture and thallus structure. The species is distributed in the Indo-Pacific region, where it is consumed as a food product eaten fresh in salads, as snack, as sushi, or in a salt preserved form (Long et al. 2020). The high nutritional composition consisting of polyunsaturated fatty acids, antioxidant activity, vitamins, minerals, and bioactive compounds makes sea grapes a nutritious food source and a good candidate to contribute to food security for the rising population, especially in coastal tropical areas (e.g., Saito et al. 2010; Nguyen et al. 2011; Paul et al. 2014; FAO, IFAD, WHO 2019). Caulerpa lentillifera are easily and sustainably culturable due to their propagation via fragmentation and the low need for expensive infrastructure or expertise (de Gaillande et al. 2017). Sea grapes are in particular cultured in open-tidal ponds as in the Philippines and Vietnam (de Gaillande et al. 2017; Zubia et al. 2020), and in the latter, pond culture is increasingly implemented at the coasts of the Central South in the Khánh Hòa province. In Japan and China, where the demand for sea grapes is especially high, land-based raceway culture is already practiced to some extent (Long et al. 2020; Zubia et al. 2020). A major factor during sea grape culture is solar radiation, which can be partially controlled through artificial shading 
of ponds. Although light is essential for seaweeds to maintain their metabolism, an excess of absorbed photosynthetically active radiation can oversaturate the electron transport chain capacity without driving the biochemical process of photosynthesis (Franklin and Forster 1997). This energy has to be emitted, e.g., through dynamic photoinhibition, a mosaic of photoprotective processes resulting in a declined transfer of excitation energy to the reaction centers in the antenna (non-photochemical quenching) (Osmond 1994; Häder et al. 1997; Hanelt et al. 1997). Otherwise, excess excitation energy can lead to irreversible photodamage or photooxidation with a loss of photosystem II (PSII) reaction centers (Demmig-Adams and Adams 1992, 1996; Aro et al. 1993). However, plants are able to respond to changing light regimes within hours to days by adjusting morphologically and physiologically (photoacclimation, e.g., Raniello et al. 2004; Marquardt et al. 2010; Aguilera and Rautenberger 2011). A common tool to quantify photosynthetic responses of seaweeds to different light conditions is the measurement of chlorophyll $a$ fluorescence using pulse-amplitude modulated (PAM) fluorometry (Maxwell and Johnson 2000). Chlorophyll fluorescence is mostly produced by PSII, and the fluorescence pattern can be traced back to changes in the transfer of excitation energy to photochemistry (photochemical quenching) and energy dissipation (non-photochemical quenching). The chlorophyll fluorescence parameter maximum quantum yield of PSII $\left(F_{v} / F_{m}\right)$ is widely used to assess the photosynthetic efficiency of PSII in dark-adapted leaves, and a decrease of which can be characterized as a result of photoinhibition (Demmig-Adams and Adams 1992; Maxwell and Johnson 2000).

Multiple studies investigated the effect of different irradiances on the photosynthesis of macroalgae and the potential of recovery after light stress exposure (García-Sánchez et al. 2012; Flores-Molina et al. 2014; Giovagnetti et al. 2018; Quintano et al. 2019). As benthic macroalgae, members of the genus Caulerpa are generally sensitive to high light radiation (Horstmann 1983; Ukabi et al. 2013; de Gaillande et al. 2017). Consistently, C. lentillifera has been found to thrive best under relatively low irradiances ( 10 to $100 \mu \mathrm{mol}$ photons $\mathrm{m}^{-2} \mathrm{~s}^{-1}$ ) of PAR and to show signs of photooxidation and photodamage under irradiances of $360 \mu \mathrm{mol}$ photons $\mathrm{m}^{-2}$ $\mathrm{s}^{-1}$ (Guo et al. 2015a; Su et al. 2017; Kang et al. 2020). However, the physiological response of $C$. lentillifera to light irradiances over time spans $>1$ week and the potential of recovery after light-induced stress exposure is still unknown, but crucial for farmers to adapt culture conditions accordingly.

For sea grape trade, the place of production and retail often differs from each other such as most of the fresh harvested seaweeds in Vietnam are exported to Japan via air freight (de Gaillande et al. 2017; Terada et al. 2018). During transport and retail, $C$. lentillifera is stored in a variety of different plastic materials. Due to the thermo-isolating properties of polystyrene (PS) (Aditya et al. 2017), containers of this material, with moisture sheets to counteract desiccation, are commonly used to pack sea grapes for shipment (Terada et al. 2018). However, for retailing to the end consumer, packaging in different plastic materials is common and the plastic properties can strongly influence the physiology of packed sea grapes (Tuong et al. 2016). In Vietnam, sea grapes are frequently stored in polyethylene terephthalate (PET) containers, having the advantage that costumers can see the product through the transparent material. PS and PET do differ not only in their transparency and thermal isolation (Aditya et al. 2017), but also in their properties regarding oxygen permeability (Zeman and Kubík 2007). During storage, algae are in danger of desiccation, leading to dehydration and consequently a loss of weight (Holzinger and Karsten 2013). Desiccation stress is in this effect comparable to salinity stress, because both result in a decrease of the alga's water potential (Kirst 1990). However in contrast to salinity stress, during desiccation, cellular ion ratios remain constant, while ion concentrations increase (Kirst 1990; Holzinger and Karsten 2013). Therefore, desiccation can result in osmotic and ionic stress, which might ultimately lead to an inhibition of the electron flow at different sites at the photosynthetic apparatus (Wiltens et al. 1978; Satoh et al. 1983; Xia et al. 2004; Gao et al. 2011). Inhibitions may lead to accumulation of reactive oxygen species (oxidative stress, Kumar et al. 2014) and potentially photodamage (Kirst 1990). Multiple studies showed the loss of water is negatively correlated with maximum quantum yield of PSII, but partly, the potential for recovery of $F_{v} / F_{m}$ after re-hydration can be observed (Gao et al. 2011; FloresMolina et al. 2014; Holzinger et al. 2015; Xu et al. 2016). In nature, intertidal seaweeds are exposed to air, e.g., during low tide, where the common strategy is to reduce the metabolic activities and cope with the desiccation stress. However, packed sea grapes have desiccation times of $\sim 1$ week. In the airfreight packaging environment (PS), $F_{v} / F_{m}$ values of $C$. lentillifera were found to decline from values of $>0.7$ to $0.60 \pm 0.22$ and $0.47 \pm 0.26$ after 4 and 8 days of desiccation, respectively. After packaging over 12 days, algae were considered dead with $F_{v} / F_{m}$ values of $0.10 \pm 0.10$ and a water loss of $72 \%$ (Terada et al. 2018). In Nha Trang, Vietnam, common practice is packaging in transparent PET containers, where algae are, additionally to desiccation stress, exposed to surrounding irradiances, in contrast to light impermeable PS packages. Therefore, light and desiccation are mutually influencing sea grape physiology.

In this study, we investigate the influence of irradiances on sea grapes in the culture and packing environment. We hypothesized that photosynthesis of $C$. lentillifera is best under pond irradiance conditions of $50 \mu \mathrm{mol}$ photons $\mathrm{m}^{-2} \mathrm{~s}^{-1}$ and would be negatively influenced by irradiances above $100 \mu \mathrm{mol}$ photons $\mathrm{m}^{-2} \mathrm{~s}^{-1}$ but could be maintained by irradiances around $25 \mu \mathrm{mol}$ photons $\mathrm{m}^{-2} \mathrm{~s}^{-1}$. Additionally, we indented to answer the question, whether sea grapes can recover from the potential stress after being transferred back to more suitable light conditions. For the packaging experiment, we hypothesized that sea grapes transported under dark conditions 
would physiologically suffer, because the non-cyclic photophosphorylation process of photosynthesis requires light in addition to a constant supply of water molecules. Furthermore, we expect that higher irradiances will cause physiological stress reactions, because desiccation might lead to a lack of water essential for photosynthesis. We are making a first attempt in defining the optimal irradiances for sea grapes in the packaging environment.

\section{Material and methods}

\section{Sample collection}

The experiments presented in this study were carried out during July to August 2019 and February to March 2020 at the laboratory facilities of the Institute of Oceanography in Nha Trang (12 $\left.14^{\prime} 25.2^{\prime \prime} \mathrm{N} ; 109^{\circ} 11^{\prime} 55.6^{\prime \prime} \mathrm{E}\right)$, located in the Central South coast of Vietnam (Fig. 1). The experiments are referred to as "culture" and "packaging" experiment, as the influences of different PARs on sea grapes during culture and under the packaging environment were investigated. For the culture experiment, sea grapes were collected at a sea grape farm ("VIJA") at Van Phong Bay (12०35'11.8" N; $109^{\circ} 13^{\prime} 26.7^{\prime \prime}$ E) in the Khánh Hòa province. Caulerpa lentillifera samples for the packaging experiment were purchased from a local market in northern Nha Trang.

\section{Chlorophyll $a$ variable fluorescence measurements}

Photosynthetic performance was determined in vivo by measuring variable chlorophyll $a$ fluorescence using a portable Diving-PAM chlorophyll fluorometer (Walz, Germany). $F_{v} \sqrt{ } F_{m}$ was measured in 7 min dark-adapted sea grape fronds (Schreiber et al. 1995; Maxwell and Johnson 2000). Sea grapes were considered unstressed when $F_{v} / F_{m}$ values were $\geq 0.7$.

\section{Culture experiment: experimental setup, measurements, and data analysis}

Based on the measured sea grape pond conditions of $50 \mu \mathrm{mol}$ photons $\mathrm{m}^{-2} \mathrm{~s}^{-1}$, two additional irradiance treatments were designed ( 25 and $100 \mu \mathrm{mol}$ photons $\mathrm{m}^{-2} \mathrm{~s}^{-1}$ ). Following common practice at sea grape farms, the algae were cultured in tray culture, where sea grapes are placed between plastic meshes. Trays $(18.5 \times 9.5 \mathrm{~cm})$ were stocked with an initial of $35.0 \pm 1.0 \mathrm{~g}$ fresh sea grapes and grown out in natural seawater in an outdoor tank under natural solar irradiances for approximately 1 month prior the start of the experiment. Three aquaria $(59 \times 25 \times 25 \mathrm{~cm} ; 37 \mathrm{~L}$, fitting 9 algae trays $)$ for the three treatments and two aquaria $(30 \times 20 \times 20 \mathrm{~cm}, 12 \mathrm{~L}$,

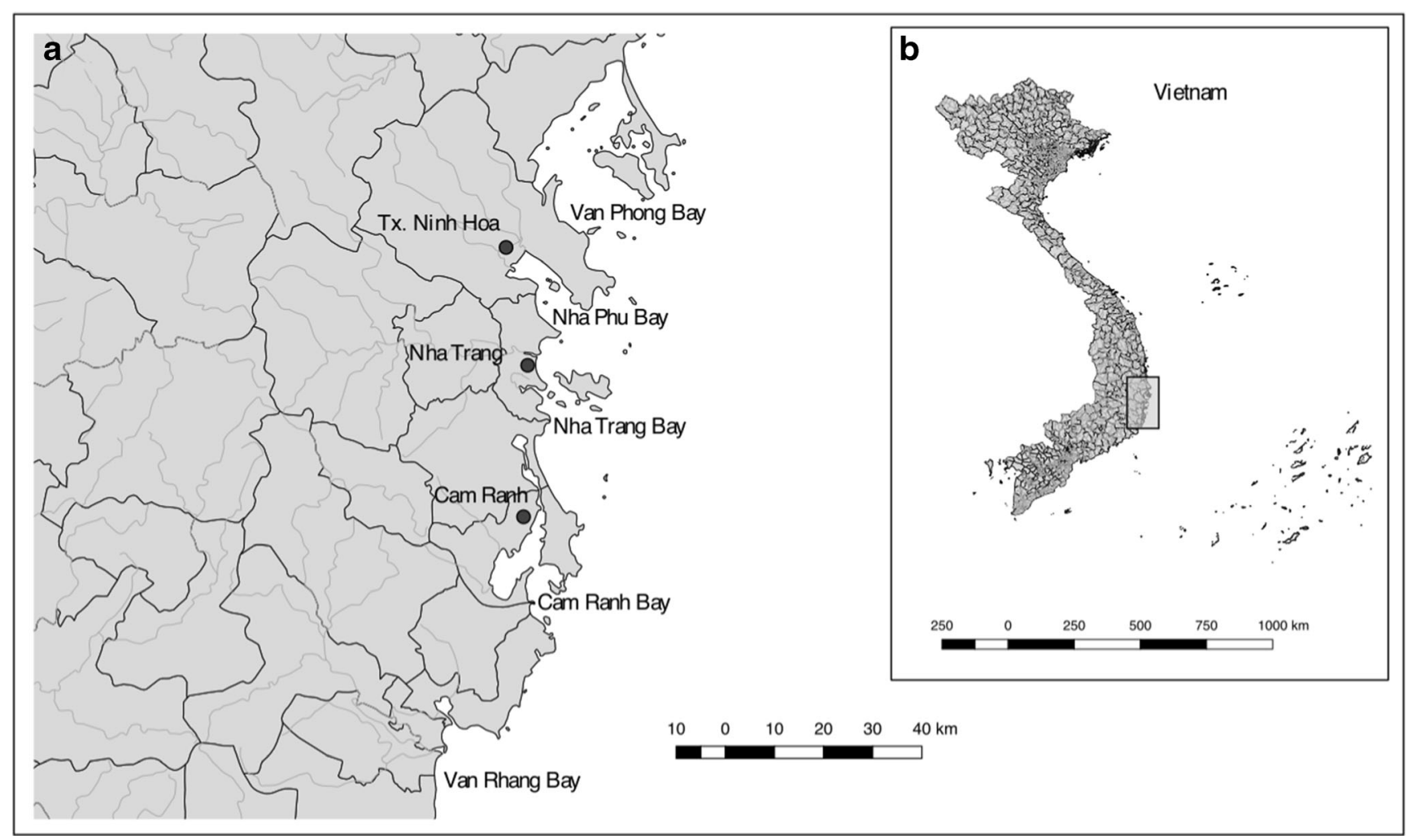

Fig. 1 a Coast around the city of Nha Trang and Van Phong Bay, where the VIJA sea grape farm is located. Each map has a scale bar at the bottom. b Map of Vietnam. 
fitting 3 algae trays) for the recovery were set up with T5 High Output Fluorescence lights $(2 \times 39 \mathrm{~W} ; 10,000 \mathrm{~K})$ for illumination in a 12:12-h light:dark rhythm. The different irradiances were adjusted by adapting the height of lamps over the aquaria and monitored using a LI-1400 datalogger (LICOR Biosciences, USA). Each treatment had a variation of $\pm 5 \mu \mathrm{mol}$ photons $\mathrm{m}^{-2} \mathrm{~s}^{-1}$ within the aquaria. For the $25 \mu \mathrm{mol}$ photons $\mathrm{m}^{-2} \mathrm{~s}^{-1}$ light treatment, gauze was additionally used for shading between the light source and the water surface. All aquaria were equipped with a constant air supply. Seawater from the adjacent coast was stored in a tank for water exchanges (every 2 days) in the experimental aquaria to ensure constant nutrient levels and water quality over the course of the experiment. Temperature, salinity, and $\mathrm{pH}$ were monitored to ensure constant conditions between and within aquaria. Prior to the start of the experiment, algae were acclimatized for 2 days $\left(50 \pm 5 \mu \mathrm{mol}\right.$ photons $\mathrm{m}^{-2} \mathrm{~s}^{-1}, 27.2 \pm 0.4{ }^{\circ} \mathrm{C}, S_{A}$ $34.6 \pm 0.5, \mathrm{pH} 8.5 \pm 0.3)$. During the experiment, changes in $F_{v} / F_{m}$ were measured using a Diving-PAM fluorometer. $F_{v} / F_{m}$ values were taken for each tray on the initial day of the experiment, as well as on days $1,7,14$, and 21. In order to examine the potential of recovery after potential lightinduced physiological stress, three replicates per treatment were transferred to the additional recovery aquaria $(50 \mu \mathrm{mol}$ photons $\mathrm{m}^{-2} \mathrm{~s}^{-1}$ ) on days 7 and 14. $F_{v} / F_{m}$ was monitored right before transfer and after 1 and 7 days under recovery irradiances $\left(50 \mu \mathrm{mol}\right.$ photons $\left.\mathrm{m}^{-2} \mathrm{~s}^{-1}\right)$. For statistical analysis, $F_{v} / F_{m}$ of sea grape trays were averaged as mean and standard deviation (SD) per treatment $(n=3)$. Statistical differences between the treatments were analyzed using one-factor ANOVA (followed by Tukey's HSD test) with the fixed factor "treatment" (levels 50, 100, $25 \mu \mathrm{mol}$ photons $\mathrm{m}^{-2} \mathrm{~s}^{-1}$ ) which was conducted for each day of measurement over the experimental course between the alga groups without transfer to recovery, with recovery after 7 and 14 days, respectively. Analyses were conducted with a significance level of $P<0.05$. All statistical tests were conducted in R Core Team (2019), and graphics were produced using ggplot2 (Wickham 2016).

\section{Packaging experiment: experimental setup, measurements, and data analysis}

The purchased sea grape fronds were already cut from the stolon, as common practice for consumption and retail of the fresh product. Sea grapes were acclimated in sea water $(28.2$ ${ }^{\circ} \mathrm{C}, S_{A} 34.2, \mathrm{pH}$ 8.5) under room irradiances for 3 days prior start of the experiment. Four sea grape fronds were placed on the long side of PET containers $(9 \times 9 \times 15 \mathrm{~cm}$, capacity of $500 \mathrm{~g}$ ) not attached to each other. A moisture sheet in each container kept the humidity constant at $100 \%$. Initial $F_{v} / F_{m}$ were measured for 50 randomly chosen fronds from the batch and initial biomass as wet-weight for sea grapes of each container was taken. Wet-weight and $F_{v} / F_{m}$ values of the stored sea grapes were quantified after storage of $2,4,8$, and 12 days under three different irradiances (darkness 0 , room irradiance $3 \pm 5$, and high irradiance $70 \pm 5 \mu \mathrm{mol}$ photons $\mathrm{m}^{-2} \mathrm{~s}^{-1}$ ). Five replicates per irradiance treatment for each time period were prepared. The containers for the dark treatment were wrapped in aluminum foil, and the caps were colored with black spray. A T5 High Output Fluorescence light $(2 \times 39$ $\mathrm{W} ; 10,000 \mathrm{~K}$ ) was placed over the containers of the high and medium light treatment, and adjustments of the heights of the lamp ensured an irradiance of $70 \pm$ $5 \mu \mathrm{mol}$ photons $\mathrm{m}^{-2} \mathrm{~s}^{-1}$ of PAR in a 12:12-h light:dark rhythm. Temperature loggers (HOBO, USA) were placed in one container of each treatment to monitor the temperature over the course of the experiments in 30-min intervals. In order to determine the potential of recovery, the sea grapes were re-immersed in seawater under room irradiances of $3 \pm$ $5 \mu \mathrm{mol}$ photons $\mathrm{m}^{-2} \mathrm{~s}^{-1}$ after the desiccation period and $F_{v} / F_{m}$ values were quantified $10 \mathrm{~min}, 3 \mathrm{~h}, 6 \mathrm{~h}$, and $24 \mathrm{~h}$ after re-immersion. Percentage of difference in $F_{v} / F_{m}$ over recovery period was calculated following the formula:

Percent of initial after desiccation $(\%)=F_{v} / F_{m t} \times\left(100 / F_{v} / F_{m i}\right)-100$,

with $F_{v} / F_{m t}$ being measured after time $t$ of desiccation and subsequent $24 \mathrm{~h}$ of re-immersion in seawater and $F_{v} / F_{m i}$ being the value measured directly after desiccation. Moisture content after each desiccation period $\left(M_{t} \%\right)$ was calculated following the formula:

$M_{t}(\%)=\left(\left(W_{\mathrm{i}}-W_{t}\right) / W_{i}\right) \times 100$,

with $W_{i}$ as the initial wet-weight of sea grapes after moisture removal at start of the experiment, and $W_{t}$ as the wet-weight after desiccation period $t$ in days (Seremet et al. 2016; Terada et al. 2018).

The additional irradiance treatment of $20 \mu \mathrm{mol}$ photons $\mathrm{m}^{-2}$ $\mathrm{s}^{-1}$ was quantified following the same protocol described above. However, physiological response was only quantified by $F_{v} / F_{m}$ values and recovery potential and moisture content were not conducted. The results are therefore presented separately as comparison between the three light treatments $(3,20$, and $70 \mu \mathrm{mol}$ photons $\mathrm{m}^{-2} \mathrm{~s}^{-1}$ ). For statistical purposes, $F_{v} / F_{m}$ of sea grapes were averaged per container and mean and SD were calculated $(n=3-5)$. Outliers were identified using Grubbs' test. Differences in $F_{v} / F_{m}$ and moisture content of sea grapes measured after the desiccation period were compared between treatments on each day with a one-factor ANOVA (followed by Tukey's HSD test) and the fixed factor "treatment" (levels $0,3,70 \mu \mathrm{mol}$ photons $\mathrm{m}^{-2} \mathrm{~s}^{-1}$ ). In order to test for differences in $F_{v} / F_{m}$ of sea grapes over the desiccation and recovery period, a one-factor ANOVA (followed by Tukey's honestly significant difference test) with the fixed factor "period" (levels "initial," "after desiccation period," "after 24 h recovery") was conducted and differences between the three light treatments were tested using a fixed term "treatment" 
(levels $0,3,70 \mu \mathrm{mol}$ photons $\mathrm{m}^{-2} \mathrm{~s}^{-1}$ ). In all cases, Levene and Shapiro-Wilk tests were carried out, and if requirements for ANOVA were not met, a Kruskal-Wallis test (followed by pairwise Dunn test with Bonferroni correction) was conducted. Analyses were conducted with a significance level of $P<0.05$. All statistical tests were conducted in R Core Team (2019), and graphics were produced using ggplot2 (Wickham 2016).

\section{Results}

\section{Culture experiment}

At the farm facility in Van Phong Bay, algae were maintained in shaded tidal ponds $\left(\sim 50 \mu \mathrm{mol}\right.$ photons $\left.\mathrm{m}^{-2} \mathrm{~s}^{-1}\right)$, with $F_{v} / F_{m}$ values indicating a good physiological state $(\geq 0.7$, unpublished data). Temperature in the experimental aquaria showed a mean of $28.4 \pm 1.2{ }^{\circ} \mathrm{C}$. Salinity and $\mathrm{pH}$ values ranged from 34.5 to 37.5 and 8.4 to 9.0 , respectively. Initial $F_{v} / F_{m}$ of all three treatments $\left(25,50\right.$, and $100 \mu \mathrm{mol}$ photons $\left.\mathrm{m}^{-2} \mathrm{~s}^{-1}\right)$ were similar, with values between $0.67 \pm 0.02$ and $0.7 \pm 0.02$ (Fig. 2). $F_{v} / F_{m}$ of sea grapes cultured under 25 and $50 \mu \mathrm{mol}$ photons $\mathrm{m}^{-2} \mathrm{~s}^{-1}$ did not change significantly from each over the 21 experimental days $(P>0.05)$. However, $F_{v} / F_{m}$ of sea grapes exposed to $100 \mu \mathrm{mol}$ photons $\mathrm{m}^{-2} \mathrm{~s}^{-1}$ was significantly lower after 7 $(0.54 \pm 0.06), 14(0.54 \pm 0.08)$, and 21 days $(0.63 \pm 0.03)$ than that of sea grapes under 25 and $50 \mu \mathrm{mol}$ photons $\mathrm{m}^{-2} \mathrm{~s}^{-1}$ $(\geq 0.70 \pm 0.03$ ), respectively (Fig. 2). However, algae cultured under $100 \mu \mathrm{mol}$ photons $\mathrm{m}^{-2} \mathrm{~s}^{-1}$ showed a trend of increase in $F_{v} \sqrt{ } F_{m}$ values from day 14 to 21 of 0.09 . After sea grapes were transferred from $100 \mu \mathrm{mol}$ photons $\mathrm{m}^{-2} \mathrm{~s}^{-1}$ to recovery
Fig. 2 Chronological change of maximum quantum yield of PSII $\left(F_{v} / F_{m}\right)$ of Caulerpa lentillifera exposed to three different irradiance treatments $(25,50$, $100 \mu \mathrm{mol}$ photons $\left.\mathrm{m}^{-2} \mathrm{~s}^{-1}\right)$. The potential of recovery under control conditions $(50 \mu \mathrm{mol}$ photons $\mathrm{m}^{-2} \mathrm{~s}^{-1}$ ) after exposure to different treatments has been investigated at different time steps: a 21 days continuous treatment without transfer to recovery conditions, $\mathbf{b} 7$ days treatment with subsequent recovery of 7 days, and $\mathbf{c} 14$ days treatment with subsequent recovery of 7 days. White and gray bars indicate the time of exposure to the different treatment irradiances or recovery, respectively. Data are mean values $\pm \mathrm{SD}(n=3)$. Letters indicate significant differences between treatments (one-factor ANOVA followed by Tukey's HSD, $P<0.05)$ and are assigned to treatments top down according to order in graph
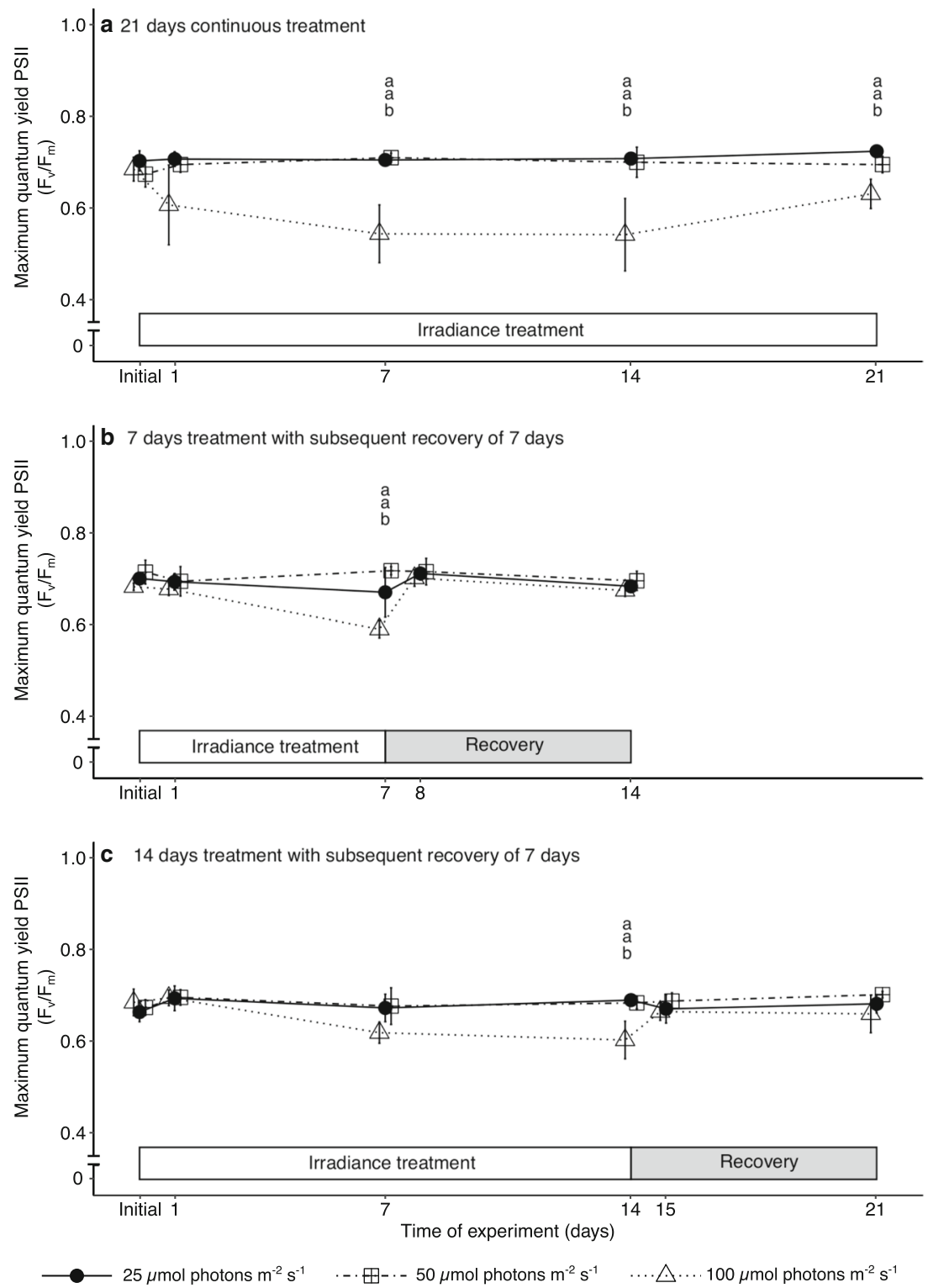


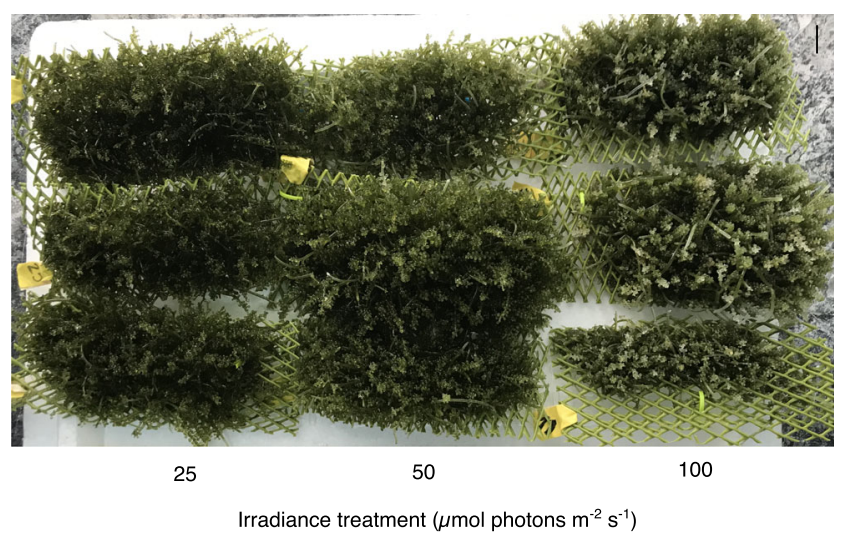

Fig. 3 Photograph of sea grape (Caulerpa lentillifera) trays $(n=3)$ after exposure to irradiances of 25,50 , and $100 \mu \mathrm{mol}$ photons $\mathrm{m}^{-2} \mathrm{~s}^{-1}$ for 21 days. Black scale bar in the right top corner represents $2 \mathrm{~cm}$ conditions $\left(50 \mu \mathrm{mol}\right.$ photons $\left.\mathrm{m}^{-2} \mathrm{~s}^{-1}\right)$ after 7 and 14 days of exposure, $F_{v} / F_{m}$ increased instantaneously by 0.11 and 0.06 over 1 day and no significant difference between all three treatments was observed. Sea grapes under high irradiances $\left(100 \mu \mathrm{mol}\right.$ photons $\left.\mathrm{m}^{-2} \mathrm{~s}^{-1}\right)$ showed a fading of color after 21 days of culture (Fig. 3).

\section{Packaging experiment}

The temperature measured by HOBO loggers in the packaging containers did not vary between the three treatments $\left(25.8 \pm 0.5^{\circ} \mathrm{C}, 25.7 \pm 0.4{ }^{\circ} \mathrm{C}\right.$, and $26.8 \pm 0.8^{\circ} \mathrm{C}$ for 0,3 , and $70 \mu \mathrm{mol}$ photons $\mathrm{m}^{-2} \mathrm{~s}^{-1}$, respectively). Sea grapes were in a good physiological state at the start of the experiment $(0.74 \pm 0.03, n=50) . F_{v} / F_{m}$ developed differently between
Fig. 4 a Maximum quantum yield of PSII $\left(F_{v} / F_{m}\right)$ and $\mathbf{b}$ moisture content (percentage of initial) of Caulerpa lentillifera packed in transparent polyethylene terephthalate (PET) containers exposed to three different irradiances $(0,3,70 \mu \mathrm{mol}$ photons $\mathrm{m}^{-2} \mathrm{~s}^{-1}$ ) over a period of 12 days, respectively. Data represent mean values $\pm \mathrm{SD}(n=4-5)$. Letters indicate significant differences between treatments (onefactor ANOVA followed by Tukey's HSD or Kruskal-Wallis test followed by pairwise Dunn test with Bonferroni correction, $P$ $<0.05)$ and are assigned to treatments top down according to order in graph a

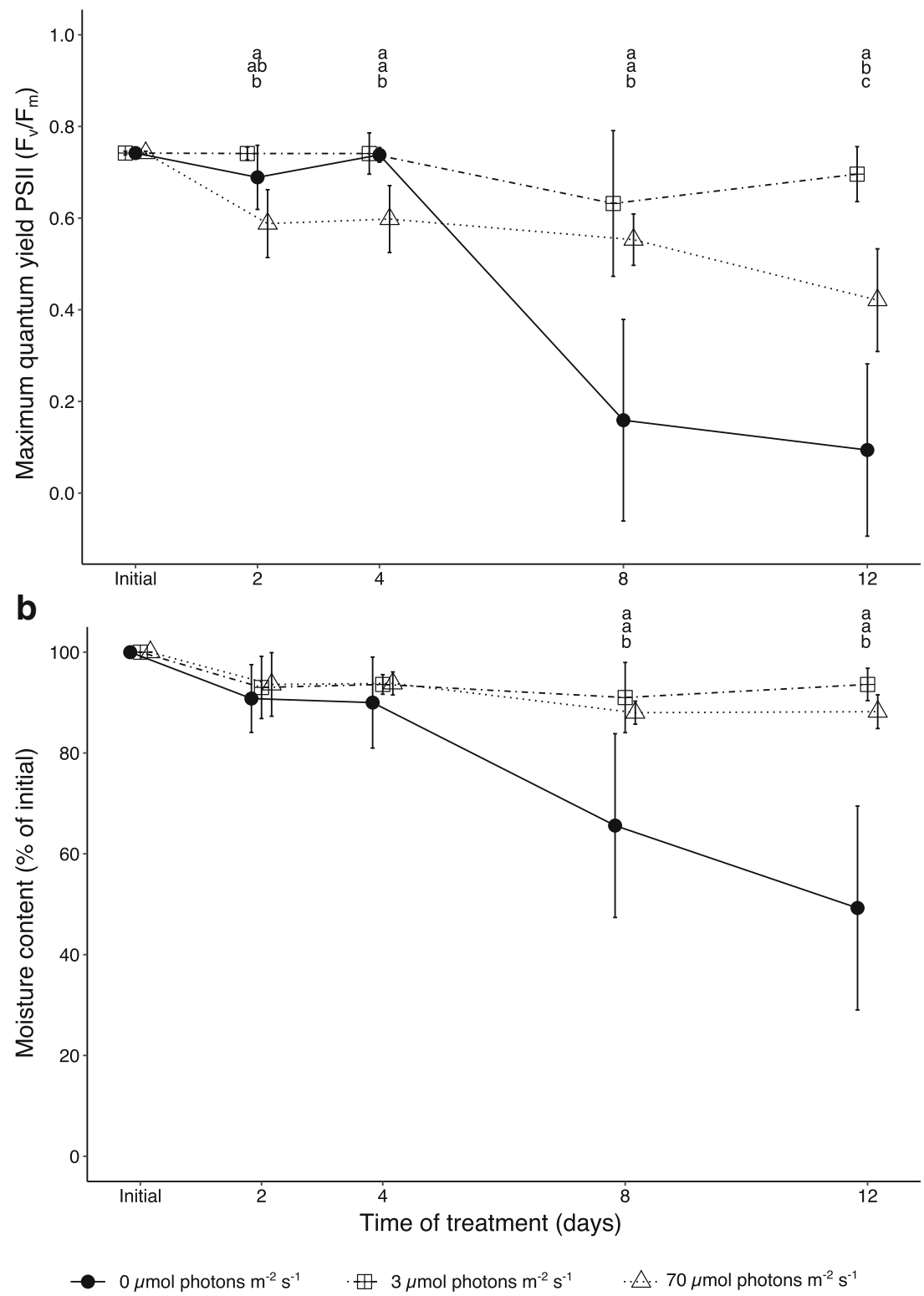


treatments over the desiccation period (Fig. 4a). Sea grapes under room irradiance $\left(3 \mu \mathrm{mol}\right.$ photons $\left.\mathrm{m}^{-2} \mathrm{~s}^{-1}\right)$ showed only a slight decrease of $F_{v} / F_{m}$ to $0.70 \pm 0.06$ after 12 days of desiccation with moisture content not dropping below $91.0 \pm 7.0 \%$ (Fig. 4b). However, desiccation over 2 days under an irradiance of $70 \mu \mathrm{mol}$ photons $\mathrm{m}^{-2} \mathrm{~s}^{-1}$ leads to significantly decreased $F_{v} / F_{m}$ of $0.59 \pm 0.07$ compared to room irradiances. The decrease continued to a value of 0.42 \pm 0.11 after 12 days. However, $F_{v} / F_{m}$ values showed a trend of recovery after re-hydration under room irradiances. The moisture content after 12 days under $70 \mu \mathrm{mol}$ photons $\mathrm{m}^{-2}$ $\mathrm{s}^{-1}$ was with $88.2 \pm 3.3 \%$, only slightly lower than in the treatment of irradiance of $3 \mu \mathrm{mol}$ photons $\mathrm{m}^{-2} \mathrm{~s}^{-1}$. Under exclusion of light, $F_{v} / F_{m}$ values remained stable over the first 4 days $(0.74 \pm 0.02)$ but decreased rapidly after 8 and 12 days of packaging to significantly lower values compared to other two treatments $(0.16 \pm 0.22$ and $0.10 \pm$ 0.19 , respectively). Exemplary pictures of sea grape fronds depict strong differences in thallus structure when packed under darkness; therefore, two pictures were provided for desiccation period of 8 and 12 days (Fig. 5). No recovery of $F_{v} / F_{m}$ was observed, but rather a further decrease of the values (Fig. 6, absolute values see Online Resource 1). Moisture content decreased strongly from $90 \pm 9.0 \%$ (4 days) to $49.25 \pm 20 \%$ (12 days) (Fig. $4 b$ ). Sea grapes under $20 \mu \mathrm{mol}$ photons $\mathrm{m}^{-2} \mathrm{~s}^{-1}$ had constantly slightly lower $F_{v} / F_{m}$ values than algae under room irradiances (Fig. 7). This difference was significantly lower 4 days under packaging ambience with $0.61 \pm 0.04$. However, $F_{v} / F_{m}$ values were consistently higher than of sea grapes under $70 \mu \mathrm{mol}$ photons $\mathrm{m}^{-2} \mathrm{~s}^{-1}$.

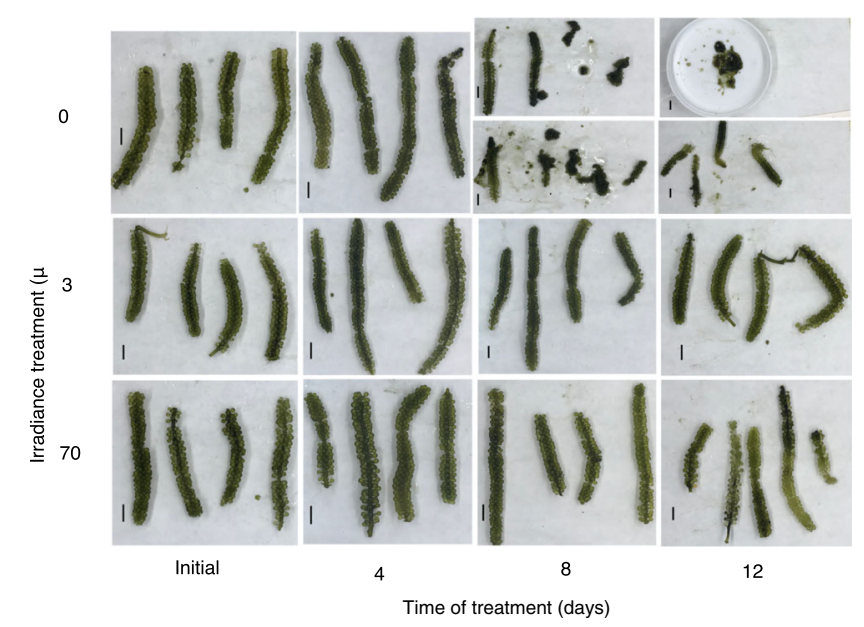

Fig. 5 Pictures of Caulerpa lentillifera packed in polyethylene terephthalate (PET) containers from initial state, and after 4, 8 and 12 days under irradiance treatments 0,3 , and $70 \mu \mathrm{mol}$ photons $\mathrm{m}^{-2} \mathrm{~s}^{-1}$. After days 8 and 12 under packaging ambience in darkness, sea grapes have very different thallus structures; therefore, two pictures are presented in order to demonstrate the pigmentation ranges of different desiccation stages of algae. Black scale bar in the left corner of each picture represents $1 \mathrm{~cm}$

\section{Discussion}

In this study, we found that light irradiances have a considerable impact on sea grapes' physiological constitution, both in the culture as well as in the packaging environment. Inappropriate irradiances seem to adversely affect the alga's physiology. However, in some cases, the sea grapes have the potential to recover. We used PAM fluorometry with $F_{v} / F_{m}$ and can confirm that this tool is suitable to quantify the physiological state of C. lentillifera (Guo et al. 2015a, b; Terada et al. 2018).

\section{Culture experiment}

Based on the results of the culture experiment, we can confirm our hypothesis that sea grapes thrive best under irradiances of 25 and $50 \mu \mathrm{mol}$ photons $\mathrm{m}^{-2} \mathrm{~s}^{-1}$ by maintaining their $F_{v} / F_{m}$ values over the course of 21 days, indicating that they were in a good physiological state and not negatively impacted by the irradiances they were exposed to. These results are in line with studies identifying $C$. lentillifera and other representatives of the genus Caulerpa (e.g., C. racemosa) as shade-adapted low light plants, which is evident for some benthic seaweeds (Horstmann 1983; Ukabi et al. 2013; de Gaillande et al. 2017). Furthermore, the decline in $F_{v} / F_{m}$ under $100 \mu \mathrm{mol}$ photons $\mathrm{m}^{-2} \mathrm{~s}^{-1}$ accompanied by the observed bleaching of the fronds is in line with observations by Guo et al. (2015b). The authors observed a decline in $F_{v} / F_{m}$ of 0.16 in sea grape fronds over 7 days exposure to $100 \mu \mathrm{mol}$ photons $\mathrm{m}^{-2} \mathrm{~s}^{-1}$ along with a significant decrease in chlorophyll $a$ content. The abrupt decrease in $F_{v} / F_{m}$ as a consequence of high irradiances is a characteristic sign of photoinhibition (Goh et al. 2012) and has been observed widely in different temperate species of the genus Caulerpa (Ukabi et al. 2013) and also in C. lentillifera (Guo et al. 2015b). However, the immediate and full recovery of $F_{v} / F_{m}$ values of $C$. lentillifera within $24 \mathrm{~h}$ after transfer to recovery conditions demonstrates the ability of the sea grapes to rapidly restore previous photosynthetic efficiency after certain stress exposure (Osmond 1994; Häder et al. 1997; Hanelt et al. 1997). This process of recovery from high irradiances was also observed in other green macroalgae (e.g., Ulva rotunda; Franklin et al. 1992). Han et al. (2007) found Ulva pertusa and Umbraulva japonica showing a decline of $F_{v} / F_{m}$ values with exposure to increasing doses of PAR. Subsequent recovery under dim light increased $F_{v} / F_{m}$ within $24 \mathrm{~h}$ completely and partially in connection with the habitat-related sensitivity, respectively. Ulva pertusa thrives in the intertidal, comparable with $C$. lentillifera (Norashikin et al. 2013). However, intertidal algae are exposed to highly fluctuating environmental conditions (Davison and Pearson 1996) and an elasticity of light requirements for photosynthesis might therefore be a coping mechanism of the seaweed survival, potentially related to their xanthophyll cycle or antioxidant activity (Han et al. 2003). The 
Fig. 6 Chronological development of maximum quantum yield of PSII $\left(F_{v} / F_{m}\right.$ as percentage of initial) of Caulerpa lentillifera under re-hydration conditions (10 min-24 h) at an irradiance of $3 \mu \mathrm{mol}$ photons $\mathrm{m}^{-2}$ $\mathrm{s}^{-1}$ after desiccation period in transparent polyethylene terephthalate (PET) containers of a 2, b $4, \mathbf{c} 8$, and $\mathbf{d} 12$ days under three different irradiances $(0,3$, $70 \mu \mathrm{mol}$ photons $\left.\mathrm{m}^{-2} \mathrm{~s}^{-1}\right)$ is depicted. Calculations of percentage of initial relate to absolute $F_{v} / F_{m}$ values measured at the end of the desiccation and the start of the recovery period (Online Resource 1). Data represent mean values $\pm \mathrm{SD}(n=5)$. No significant differences were found (onefactor ANOVA followed by Tukey's HSD or Kruskal-Wallis test followed by pairwise Dunn test with Bonferroni correction, $P$ $<0.05)$

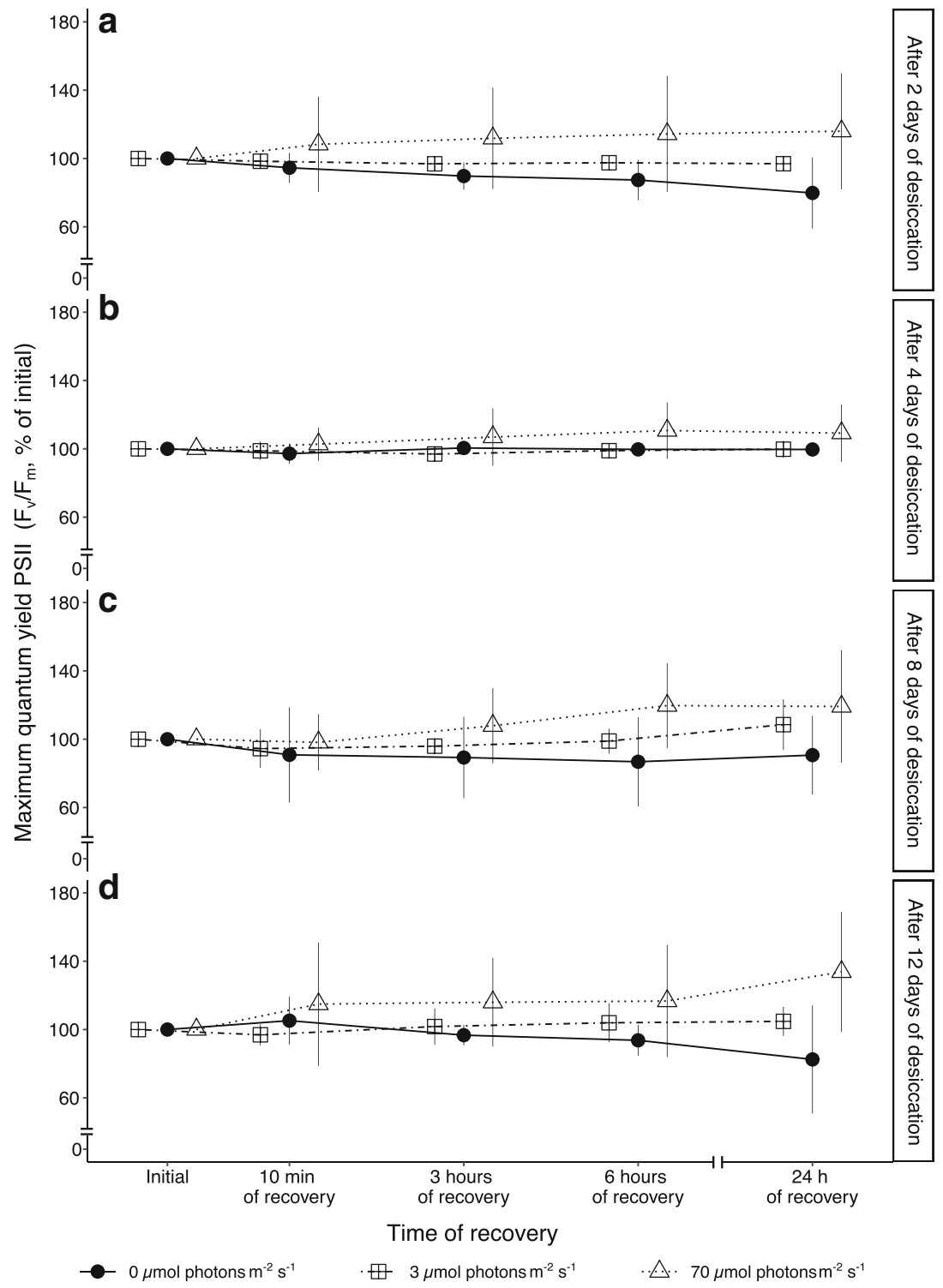

increase of $F_{v} / F_{m}$ within the third week under $100 \mu \mathrm{mol}$ photons $\mathrm{m}^{-2} \mathrm{~s}^{-1}$ might potentially be due to a long-term acclimation of $C$. lentillifera to the changed irradiance environment. Longterm photoacclimation as an answer to changes in photo-regime, e.g., through morphological and physiological alternations, has been observed in several Caulerpa species (e.g., Horstmann 1983; Riechert and Dawes 1986; Raniello et al. 2004, 2006; Malta et al. 2005; Marquardt et al. 2010). Raniello et al. (2004) describe the capacity of C. racemosa to reorganize the photosynthetic apparatus, change pigment composition, and eventually display different photosynthetic traits in relation to light availability over seasons and in the canopy. The observed trends are particularly interesting taking into account the economic value of sea grapes. Photoinhibition can decrease productivity and growth and therefore critically impact the harvest of $C$. lentillifera (Goh et al. 2012). However, if sea grapes have the capacity to acclimate to higher irradiances, farmers could use the opportunity to their benefits. Therefore, this potential capacity should be explored further.

\section{Packaging experiment}

We attempted to contribute in defining suitable storage irradiances for sea grapes. The stable $F_{v} / F_{m}$ values with only minimal loss of moisture content of $C$. lentillifera stored under room irradiances $\left(3 \mu \mathrm{mol}\right.$ photons $\left.\mathrm{m}^{-2} \mathrm{~s}^{-1}\right)$ in PET containers suggest a good physiological state of the alga and thus a sufficient quality of the product for the end consumer even after 12 days of storage. However, Terada et al. (2018) found $F_{v} / F_{m}$ of $C$. lentillifera packed in PS containers (irradiances of $3 \mu \mathrm{mol}$ photons $\mathrm{m}^{-2} \mathrm{~s}^{-1}$ ) declining to $0.10 \pm 0.10$ along with $72 \%$ critical water loss and absence of recovery after re- 
Fig. 7 Maximum quantum yield of PSII $\left(F_{v} / F_{m}\right)$ of Caulerpa lentillifera during desiccation period packed in transparent polyethylene terephthalate (PET) containers under three different irradiances $(3,20,70 \mu \mathrm{mol}$ photons $\mathrm{m}^{-2} \mathrm{~s}^{-1}$ ) for a period of 2 , 4,8 , and 12 days. Data are mean values $\pm \mathrm{SD}(n=3-5)$. Letters indicate significant differences between treatments (one-factor ANOVA followed by Tukey's HSD or Kruskal-Wallis test followed by pairwise Dunn test with Bonferroni correction, $P<0.05)$ and are assigned to treatments top down according to order in graph

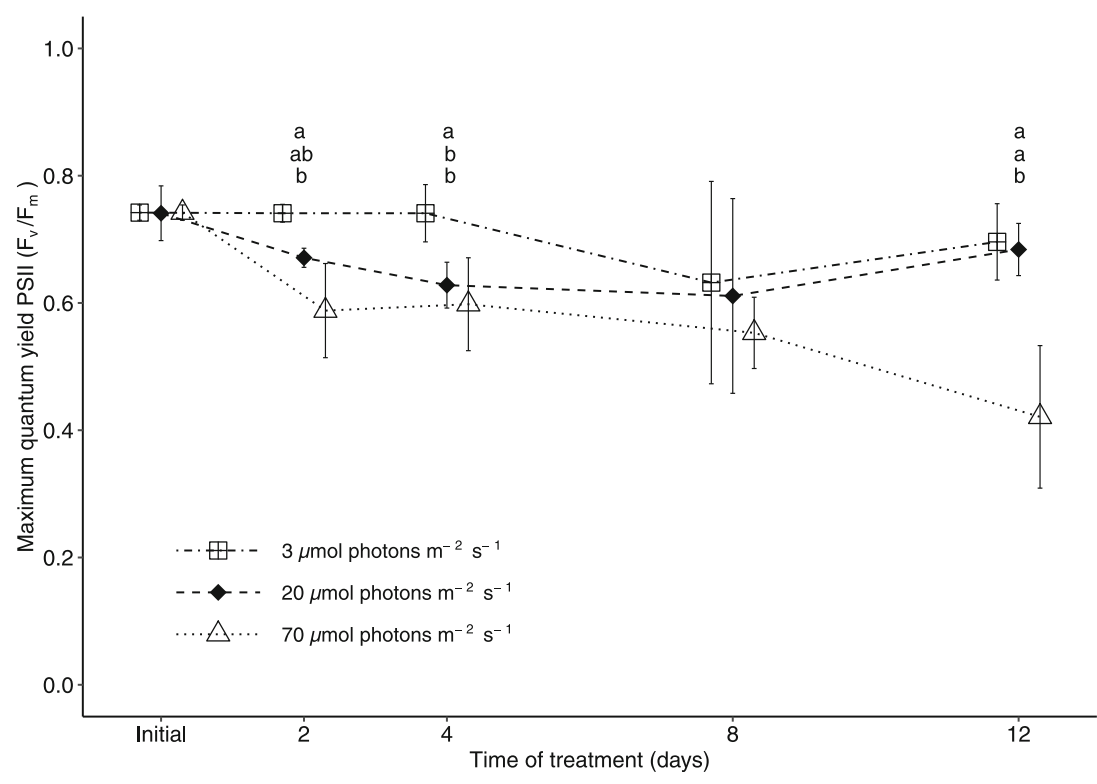

immersion in sea water. The authors suggest this might be caused by cellular alterations resulting in dysfunctional algae. These results imply potentially more favorable conditions of storage in PET than PS containers. However, potential explanations for the strong deviation between the results are the properties of packaging materials (PET vs PS) and different storage temperatures $\left(\sim 26^{\circ} \mathrm{C}\right.$ vs $\left.20^{\circ} \mathrm{C}\right)$. Polymer type of containers has been found to influence the amount of total aerobic bacteria on packed sea grapes (Tuong et al. 2016), possibly due to differences in gas and especially oxygen permeability (Zeman and Kubík 2007; Siracusa 2012). Accordingly, the microbial community was also found to influence the postharvest physiology of seaweeds (Liot et al. 1993).

Our hypothesis that packaging of sea grapes under dark $\left(0 \mu \mathrm{mol}\right.$ photons $\left.\mathrm{m}^{-2} \mathrm{~s}^{-1}\right)$ as well as high light $(70 \mu \mathrm{mol}$ photons $\mathrm{m}^{-2} \mathrm{~s}^{-1}$ ) environments negatively influences the physiological status of $C$. lentillifera was supported by the results. Absence of light clearly constitutes a source of limitation stress for the seaweeds. Insufficient irradiance leads to a lack of carbon assimilation by plants, and under carbohydrate starvation, plants have to substitute sugar with protein and lipids before running out of energy to sustain metabolism (Brouquisse et al. 1998; Lavaud et al. 2020). However, some polar seaweeds have been found to be adapted to survival under extended periods of darkness, e.g., through substantial starch storages (Gómez et al. 1997; Weykam et al. 1997; Wiencke et al. 2007). Other plants are physiologically not that well equipped for extended dark or even light limiting periods, as studies on, for example, Laminaria, sea grasses, and microalgae show (Smayda and Mitchell-Innes 1974; Dieck 1993; Silva et al. 2013). Caulerpa paspaloides was found to have significant lower starch concentrations following overwintering, along with stolons forming a higher percentage of the whole thalli biomass compared to the alga's fronds
(O'Neal and Prince 1988). Thus, cutting of the sea grape's stolons before packaging might even decrease carbon storage of the algae and therefore adversely affect survival. Over 4 days of packaging in darkness, sea grapes were still active with minor loss of water, indicating sufficient storage of essential nutrients. But the rapid decrease of moisture content over 8 and 12 days of packaging with simultaneously declining $F_{v} / F_{m}$ values and without potential of recovery indicates an irreversible damage of the photosystem. However, a high variability in moisture contents, $F_{v} / F_{m}$ values, and thallus structure (soft vs intact) after 8 and 12 days of desiccation under dark conditions might be traced back to unequal nutrient storages of the organisms. Interestingly, the decreased photosynthetic performance provoked by high light stress was reversible under recovery conditions, whereas induced by darkness, a further decrease of $F_{v} / F_{m}$ was observed. This indicates that desiccation under darkness distinctively affected the ultrastructure of the sea grape's membrane (Davison and Pearson 1996; Holzinger and Karsten 2013; Flores-Molina et al. 2014), whereas the thalli under light stress were still intact but showed a faster decrease of $F_{v} / F_{m}$. Desiccation and the resulting hypersalinity in the cells seem to affect the process of photosynthesis at different steps. It might have restricted the inflow of water molecules as essential electron donor at the water splitting side of PSII, as well as interrupting the electron transport from PSII to PSI and energy transfer between pigments (Satoh et al. 1983; Gao et al. 2011). The reduced ability to use absorbed light energy requires a corresponding increase in processes that dissipate excess solar energy to avoid damage (Davison and Pearson 1996). Consequently, desiccation stress seems to lower the threshold of increased non-photochemical quenching occurrence caused by high irradiances. This observation could explain the successive decrease of $F_{v} / F_{m}$ with increasing irradiances $(3,20$, 
$70 \mu \mathrm{mol}$ photons $\mathrm{m}^{-2} \mathrm{~s}^{-1}$ ), which was observed under desiccation conditions. The decreased $F_{v} / F_{m}$ under $20 \mu \mathrm{mol}$ photons $\mathrm{m}^{-2} \mathrm{~s}^{-1}$ compared to room irradiances in the packaging ambience on one hand and stable photosynthesis activity under similar irradiances under immersed conditions suggests that energy absorption exceeded the limit to be used in photochemical quenching under the desiccation packaging conditions. The potential of recovery and the apparently intact thallus structure, however, imply that no lasting photodamage appeared, but that protective mechanisms were still intact.

\section{Conclusion}

Our objective to investigate suitable irradiances for sea grapes in culture and packaging conditions resulted in certain recommendations for sea grape farmers and retailers. For outdoor sea grape culture, our results suggest that shading of sea grapes is beneficial. Additionally, PET containers equipped with moisture sheets seem to be a suitable opportunity for the product's storage over at last 12 days, but the additional provision of a dim light environment is essential to maintain a good physiological state of $C$. lentillifera and therefore offer a fresh product of high quality to the end consumer.

Supplementary Information The online version contains supplementary material available at https://doi.org/10.1007/s10811-020-02322-x.

Acknowledgments Open Access funding enabled and organized by Projekt DEAL The authors would like to thank Mr. Hoang Trung Du and other researchers and staff at the Institute of Oceanography for the helpful support on-site.

Authors' contributions LS, KS, and AK designed the study; LS carried out the experiments and wrote the initial draft of the manuscript; all authors contributed to improving the manuscript; AK and KS secured the funding.

Funding This research was conducted with Leibniz Centre for Tropical Marine Research in-house funding issued under \#6073.

\section{Compliance with ethical standards}

Conflict of interest The authors declare that they have no conflict of interest.

Open Access This article is licensed under a Creative Commons Attribution 4.0 International License, which permits use, sharing, adaptation, distribution and reproduction in any medium or format, as long as you give appropriate credit to the original author(s) and the source, provide a link to the Creative Commons licence, and indicate if changes were made. The images or other third party material in this article are included in the article's Creative Commons licence, unless indicated otherwise in a credit line to the material. If material is not included in the article's Creative Commons licence and your intended use is not permitted by statutory regulation or exceeds the permitted use, you will need to obtain permission directly from the copyright holder. To view a copy of this licence, visit http://creativecommons.org/licenses/by/4.0/.

\section{References}

Aditya L, Mahlia TMI, Rismanchi B, Ng HM, Hasan MH, Metselaar HSC, Muraza O, Aditiya HB (2017) A review on insulation materials for energy conservation in buildings. Renew Sust Energ Rev 73:1352-1365

Aguilera J, Rautenberger R (2011) Oxidative stress tolerance strategies of intertidal macroalgae. In: Abele D, Vasquez-Medina JP, ZentenoSavin T (eds) Oxidative stress in aquatic ecosystems. Blackwell, Oxford, pp 58-71

Aro EM, McCaffery S, Anderson JM (1993) Photoinhibition and D1 protein degradation in peas acclimated to different growth irradiances. Plant Physiol 103:835-843

Brouquisse R, Gaudillère J-P, Raymond P (1998) Induction of a carbonstarvation-related proteolysis in whole maize plants submitted to light/dark cycles and to extended darkness. Plant Physiol 117: 1281-1291

Davison IR, Pearson GA (1996) Stress tolerance in intertidal seaweeds. J Phycol 32:197-211

de Gaillande C, Payri C, Remoissenet G, Zubia M (2017) Caulerpa consumption, nutritional value and farming in the Indo-Pacific region. J Appl Phycol 29:2249-2266

Demmig-Adams B, Adams WW (1992) Photoprotection and other responses of plants to high light stress. Annu Rev Plant Physiol Plant Mol Biol 43:599-626

Demmig-Adams B, Adams WW (1996) Xanthophyll cycle and light stress in nature: uniform response to excess direct sunlight among higher plant species. Planta 198:460-470

Dieck IT (1993) Temperature tolerance and survival in darkness of kelp gametophytes (Laminariales, Phaeophyta) - ecological and biogeographical implications. Mar Ecol Prog Ser 100:253-264

FAO, IFAD, WHO, et al (2019) The State of Food Security and Nutrition in the World 2019. Safeguarding against economic slowdowns and downturns. Rome

Flores-Molina MR, Thomas D, Lovazzano C, Núñez A, Zapata J, Kumar M, Correa JA, Contreras-Porcia L (2014) Desiccation stress in intertidal seaweeds: effects on morphology, antioxidant responses and photosynthetic performance. Aquat Bot 113:90-99

Franklin L, Forster R (1997) The changing irradiance environment: consequences for marine macrophyte physiology, productivity and ecology. Eur J Phycol 32:207-232

Franklin L, Levavasseur G, Osmond CB, Henley WJ, Ramus J (1992) Two components of onset and recovery during photoinhibition of Ulva rotundata. Planta 186:399-408

Gao S, Shen S, Wang G, Niu J, Lin A, Pan G (2011) PSI-driven cyclic electron flow allows intertidal macro-algae Ulva sp. (Chlorophyta) to survive in desiccated conditions. Plant Cell Physiol 52:885-893

García-Sánchez M, Korbee N, Pérez-Ruzafa IM, Marcos C, Domínguez B, Figueroa FL, Pérez-Ruzafa Á (2012) Physiological response and photoacclimation capacity of Caulerpa prolifera (Forsskål) J.V. Lamouroux and Cymodocea nodosa (Ucria) Ascherson meadows in the Mar Menor lagoon (SE Spain). Mar Environ Res 79:37-47

Giovagnetti V, Han G, Ware MA, Ungerer P, Qin X, Wang W-D, Kuang T, Shen J-R, Ruban AV (2018) A siphonous morphology affects light-harvesting modulation in the intertidal green macroalga Bryopsis corticulans (Ulvophyceae). Planta 247:1293-1306

Goh C-H, Ko S-M, Koh S, Kim Y-J, Bae H-J (2012) Photosynthesis and environments: photoinhibition and repair mechanisms in plants. $\mathrm{J}$ Plant Biol 55:93-101 
Gómez I, Weykam G, Klöser H, Wiencke C (1997) Photosynthetic light requirements, metabolic carbon balance and zonation of sublittoral macroalgae from King George Island (Antarctica). Mar Ecol Prog Ser 148:281-293

Guo H, Yao J, Sun Z, Duan D (2015a) Effects of salinity and nutrients on the growth and chlorophyll fluorescence of Caulerpa lentillifera. Chin J Oceanol Limnol 33:410-418

Guo H, Yao J, Sun Z, Duan D (2015b) Effect of temperature, irradiance on the growth of the green alga Caulerpa lentillifera (Bryopsidophyceae, Chlorophyta). J Appl Phycol 27:879-885

Häder D-P, Lebert M, Flores-Moya A, Jiménez C, Mercado J, Salles S, Aguilera J, Figuero FL (1997) Effects of solar radiation on the photosynthetic activity of the red alga Corallina elongata Ellis et Soland. J Photochem Photobiol B 37:196-202

Han T, Han Y-S, Kain JM, Häder D-P (2003) Thallus differentiation of photosynthesis, growth, reproduction, amd UV-B sensitivity in the green alga Ulva pertusa (Chlorophyceae). J Phycol 39:712-721

Han Y-S, Kang SH, Han T (2007) Photosynthesis and photoinhibition of two green macroalgae with contrasting habitats. J Plant Biol 50: $410-416$

Hanelt D, Wiencke C, Karsten U, Nultsch W (1997) Photoinhibition and recovery after high light stress in different developmental and lifehistory stages of Laminaria saccharina (Phaeophyta). J Phycol 33: 387-395

Holzinger A, Karsten U (2013) Desiccation stress and tolerance in green algae: consequences for ultrastructure, physiological and molecular mechanisms. Front Plant Sci 4:00327

Holzinger A, Herburger K, Kaplan F, Lewis LA (2015) Desiccation tolerance in the chlorophyte green alga Ulva compressa: does cell wall architecture contribute to ecological success? Planta 242:477-492

Horstmann U (1983) Cultivation of the green alga, Caulerpa racemosa, in tropical waters and some aspects of its physiological ecology. Aquaculture 32:361-371

Kang LK, Huang YJ, Lim WT, Hsu PH, Hwang PA (2020) Growth, pigment content, antioxidant activity, and phytoene desaturase gene expression in Caulerpa lentillifera grown under different combinations of blue and red light-emitting diodes. J Appl Phycol 32:19711982

Kirst GO (1990) Salinity tolerance of eukaryotic marine algae. Annu Rev Plant Physiol 41:21-53

Kumar M, Kumari P, Reddy CRK, Jha B (2014) Salinity and desiccation induced oxidative stress acclimation in seaweeds. Adv Bot Res 71: 91-123

Lavaud R, Filgueira R, Nadeau A, Steeves L, Guyondet T (2020) A Dynamic Energy Budget model for the macroalga Ulva lactuca. Ecol Model 418:108922

Liot F, Colin A, Mabeau S (1993) Microbiology and storage life of fresh edible seaweeds. J Appl Phycol 5:243-247

Long H, Gu X, Zhu Z, Wang C, Xia X, Zhou N, Liu X, Zhao M (2020) Effects of bottom sediment on the accumulation of nutrients in the edible green seaweed Caulerpa lentillifera (sea grapes). J Appl Phycol 32:705-716

Malta E, Ferreira D, Vergara J, Pérez-Lloréns J (2005) Nitrogen load and irradiance affect morphology, photosynthesis and growth of Caulerpa prolifera (Bryopsidales: Chlorophyta). Mar Ecol Prog Ser 298:101-114

Marquardt R, Schubert H, Varela DA, Huovinen P, Henriquez L, Buschmann AH (2010) Light acclimation strategies of three commercially important red algal species. Aquaculture 299:140-148

Maxwell K, Johnson GN (2000) Chlorophyll fluorescence-a practical guide. J Exp Bot 51:659-668

Nguyen VT, Ueng J-P, Tsai G-J (2011) Proximate composition, total phenolic content, and antioxidant activity of seagrape (Caulerpa lentillifera). J Food Sci 76:C950-C958

Norashikin A, Harah ZM, Sidik BJ (2013) Intertidal seaweeds and their multi-life forms. J Fish Aquat Sci 8:452-461
O'Neal S, Prince JS (1988) Relationship between seasonal growth, photosynthetic production and apex mortality of Caulerpa paspaloides (Chlorophyceae). Mar Biol 72:61-67

Osmond CB (1994) What is photoinhibition? Some insights from comparisons of shade and sun plants. In: Baker NR, Bowyer JR (eds) Photoinhibition of photosynthesis-from molecular mechanisms to the field. BIOS Scientific Publishers, Los Angeles, pp 1-24

Paul NA, Neveux N, Magnusson M, de Nys R (2014) Comparative production and nutritional value of "sea grapes" - the tropical green seaweeds Caulerpa lentillifera and C. racemosa. J Appl Phycol 26: $1833-1844$

Pereira L (2020) Characterization of bioactive components in edible algae. Mar Drugs 18:65

Quintano E, Celis-Plá PSM, Martínez B, Díez I, Muguerza N, Figueroa FL, Gorostiaga JM (2019) Ecophysiological responses of a threatened red alga to increased irradiance in an in situ transplant experiment. Mar Environ Res 144:166-177

R Core Team (2019) A language and environment for statistical computing. R Foundation for Statistical Computing, Vienna

Raniello R, Lorenti M, Brunet C, Buia M (2004) Photosynthetic plasticity of an invasive variety of Caulerpa racemosa in a coastal Mediterranean area: light harvesting capacity and seasonal acclimation. Mar Ecol Prog Ser 271:113-120

Raniello R, Lorenti M, Brunet C, Buia MC (2006) Photoacclimation of the invasive alga Caulerpa racemosa var. cylindracea to depth and daylight patterns and a putative new role for siphonaxanthin. Mar Ecol 27:20-30

Riechert R, Dawes CJ (1986) Acclimation of the green alga Caulerpa racemosa var. uvifera to light. Bot Mar 29:533-537

Saito H, Xue C, Yamashiro R, Moromizato S, Itabashi Y (2010) High polyunsaturated fatty acid levels in two subtropical macroalgae, Cladosiphon okamuranus and Caulerpa lentillifera. J Phycol 46: 665-673

Satoh K, Smith CM, Fork DC (1983) Effects of salinity on primary processes of photosynthesis in the red alga Porphyra perforata. Plant Physiol 73:643-647

Schreiber U, Bilger W, Neubauer C (1995) Chlorophyll fluorescence as a nonintrusive indicator for rapid assessment of in vivo photosynthesis. In: Schulze E-D, Caldwell MM (eds) Ecophysiology of photosynthesis. Springer, Berlin, pp 49-70

Seremet L, Botez E, Nistor O-V, Andronoiu DG, Mocanu G-D (2016) Effect of different drying methods on moisture ratio and rehydration of pumpkin slices. Food Chem 195:104-109

Silva J, Barrote I, Costa MM, Albano S, Santos R (2013) Physiological responses of Zostera marina and Cymodocea nodosa to lightlimitation stress. PLoS One 8:e81058

Siracusa V (2012) Food packaging permeability behaviour: a report. Int J Polym Sci 2012:1-11

Smayda TJ, Mitchell-Innes B (1974) Dark survival of autotrophic, planktonic marine diatoms. Mar Biol 25:195-202

Su X, Zou X, Zhu J, Huang H, Liu R, Bao S (2017) Effects of light intensity on chlorophyll fluorescence characteristics of Caulerpa lentillifera. J Fish Sci China 24:783-790

Terada R, Nakazaki Y, Borlongan IA, Endo H, Nishihara GN (2018) Desiccation effect on the PSII photochemical efficiency of cultivated Japanese Caulerpa lentillifera under the shipping package environment. J Appl Phycol 30:2533-2538

Tuong LT, Thi N, Trang M, Boi VN, Dai NH (2016) Effect of packaging to quality and shelf-life of fresh sea grapes (Caulerpa lentillifera $\mathrm{J}$. Agardh, 1837). J Fish Sci Technol 3:22-27

Ukabi S, Dubinsky Z, Steinberger Y, Israel A (2013) Temperature and irradiance effects on growth and photosynthesis of Caulerpa (Chlorophyta) species from the eastern Mediterranean. Aquat Bot 104:106-110

Weykam G, Thomas DM, Wiencke C (1997) Growth and photosynthesis of the Antarctic red algae Palmaria decipiens (Palmariales) and 
Iridaea cordata (Gigartinales) during and following extended periods of darkness. Phycologia 36:395-405

Wickham H (2016) ggplot2: elegant graphics for data analysis, 2nd Edn. Springer, Cham

Wiencke C, Clayton MN, Gómez I, Iken K, Lüder UH, Amsler CD, Karsten U, Hanelt D, Bischof K, Dunton K (2007) Life strategy, ecophysiology and ecology of seaweeds in polar waters. Rev Environ Sci Biotechnol 6:95-126

Wiltens J, Schreiber U, Vidaver W (1978) Chlorophyll fluorescence induction: an indicator of photosynthetic activity in marine algae undergoing desiccation. Can J Bot 56:2787-2794

Xia J, Li Y, Zou D (2004) Effects of salinity stress on PSII in Ulva lactuca as probed by chlorophyll fluorescence measurements. Aquat Bot 80: 129-137
Xu D, Zhang X, Wang Y, Fan X, Miao Y, Ye N, Zhuang Z (2016) Responses of photosynthesis and nitrogen assimilation in the green-tide macroalga Ulva prolifera to desiccation. Mar Biol 163:9

Zeman S, Kubík L (2007) Permeability of polymeric packaging materials. Tech Sci 10:33-34

Zubia M, Draisma SGA, Morrissey KL, Varela-Álvarez E, de Clerck O (2020) Concise review of the genus Caulerpa J. V. Lamouroux. J Appl Phycol 32:23-39

Publisher's note Springer Nature remains neutral with regard to jurisdictional claims in published maps and institutional affiliations. 